\title{
BHARAT TOWARDS ATMANIRBHARTA: A TWITTER BASED ANALYSIS USING NVIVO
}

\author{
Rajat Sharma \\ Research Scholar \\ School of Commerce and Management Studies \\ Central University of Himachal Pradesh, Dharamshala \\ Dr. Sahil Gupta \\ Assistant Professor \\ IMS Ghaziabad University Courses Campus, Ghaziabad
}

\begin{abstract}
Background It's been over a year now and Covid-19 is still among us and most of the countries are still in fight against Covid-19. Lockdown was the only possible solution but the impact of lockdowns on economies was devastated. Atmanirbhar Bharat (Self-Reliant India) a Covid-19 pandemic economic package of twenty lakh crore rupees was announced by Indian central government on the $12^{\text {th }}$ of May, 2020. The package was released to make the country independent and to primarily empower the poor, labourers, and migrants who were adversely affected by Covid-19.
\end{abstract}

Research Methodology The research paper is of qualitative type and the research methodology has two parts- in the first, the literature has been reviewed regarding the impact of Covid-19 on various sectors globally and in the second part- extracted tweets has been analysed using NVivo and the main parameters- themes, sentiment, word map and word cloud are noted down.

Findings The paper extracted various themes under the Atmanirbhar Bharat and the top five themes are related to defence and products. Majority of the tweets are on the positive side as shown by the sentiment analysis. The majority of tweets are from Asia as shown by the word map.

Conclusion Lack of beds in hospitals, lack of oxygen supply, and lack of basic facilities for Covid-19 patients have debunk the health system. Though the government made the announcement related to the Atmanirbharbharat very easily, it is going to be very difficult to make it accessible for the common man.

Keywords: Atmanirbhar Bharat, Covid-19, Economy, NVivo, Twitter Analysis, Thematic Analysis, Sentiment Analysis

\section{INTRODUCTION}

Covid-19 a virus having a diameter of less than $140 \mathrm{~nm}$ has stopped the pace of the world from the last year. Most of the countries are under its influence and governments are taking necessary actions to control further outbreaks. The virus was also emerged in 2002 and 2012 in the form of SARS (Severe Acute Respiratory Syndrome) and MERS (Middle East Respiratory Syndrome) but this SARS Cov-2 is much more dangerous than the previous two. Covid-19 is not only responsible for altering the health sector but it also affected the Information Technology sector, Travel and Tourism, Manufacturing and all other sectors badly throughout the world. Lockdown was the first precautionary measure in front of the governments to prevent the outbreak of the virus irrespective of the healthcare industry has emerged vastly in India( Sood et al, 2019)

Wuhan was the centre and China was the first country to imposed the lockdown in Hubei Provinces on January 23, 2020. Italy was the first country to impose the national lockdown of 21 days and by the end of May, the whole world was reeling from this deadly virus (Staff, 2020). Now the countries are trying to revive their economies that were hit hard by the pandemic by taking small steps in their own way. America President announces a package of $\$ 1.9$ Trillion to revitalize a flagging economy and to speed up the nation's response to the coronavirus pandemic. It is a two-step plan of recovery and rescue (Narayan, 2021). France was hit hard by the coronavirus and declared it is one of 
Europe's deepest recessions due to lockdown. The country unfolds the plan to spend 100 billion Euros to revive the economy. The package earmarks 35 billion Euros to make the economy more competitive, 30 billion Euros for energy policies and remaining for supporting the jobs (Irish Times, 2020). Chancellor Rishi Sunak has already announced a "plan for jobs" to stimulate Britain's battered economy. the plans are divided into further classification as Vat cut, Work, Green Measures, Stamp Holiday Duty, and others. India's central government on 12 May 2020 announced a package Atmanirbhar Bharat Abhiyan (Self- Reliant India) to revive the shattered economy due to the coronavirus pandemic of 20 lakh crore rupees.

The five pillars that laid the foundation of Atmanirbhar Bharat are 1. Economy, 2. Infrastructure, 3. The System, 4. Demography and 5. Demand (Japee, 2020. Dubey and Dubey, 2020). According to Economic Diplomacy Division, the stimulus package is expected to provide investment support to multiple sectors, boost employment growth within the country, foster self-sufficiency within all sectors.

The biggest problem in fighting against coronavirus are mutations that occur in it after a hiatus. Several new variants have been reported in United Kingdom, South Africa, Brazil by the end of 2020 and all strains are more infectious than the original one. Tremendous increase in Covid-19 cases have seen especially in Maharashtra because of that mutated spike protein in coronavirus (Supriya, 2021). Despite this, at the end of February, India's election authorities announced elections in five states for 824 seats and Cricket board allowed 1,30,000 spectators to watch two international Cricket games in Gujarat (Biswas, 2021).

Vaccination drive is also not so easy to handle. The central government has now permitted manufacturers to supply $50 \%$ of the ordered doses to states and for this stated will need at least 40,000 crores to fund the drive (Mahajan, 2021). As of report by Ministry of Health and Family Welfare, a total of 15.89 crore doses administered across the country out of which more than 12.92 crore get their first dose of vaccine and approximately 2.97 crore received their second dose of coronavirus vaccine.

\section{THEORETICAL FOUNDATION} Covid-19 and its impact

As the world enters into 2021 the second wave of Covid-19 is there to hit the world and as expected by experts the second wave of the pandemic is much more dangerous than the first. In India the vaccine for Covid-19 was officially begin on the $16^{\text {th }}$ of January, 2021 was the only news of relief as the country launched one of the world's biggest vaccination programs.

The second wave of the coronavirus is much devastating than the first in two ways; first, the abrupt increase in new cases from 10,000 to 40,000 in the month of February to April has taken less than 40 days. In September 2020, this journey took 83 days. Secondly, many more of the cases testing positive are asymptomatic or with mild symptoms and majority of the cases are in between the age group of 30-60 (Covid-19 Commission, 2021).

UNICEF (United Nation Children Fund) along with World Health Organisation are in continuous to support government led efforts to prevent the further spread of the pandemic. UNICEF India's Covid-19 Response Plan supports the government of India and is also active in 17 states to enable results across five response pillars: 1) Risk Communication and Community Engagement (RCCE) and Social Media Engagement, 2) Improve Infection Prevention and Control (IPC) and provide critical and Water, Sanitation and Hygiene (WASH) supplies, 3) Support the supervision of continued access to essential health and nutrition services for women, children, and vulnerable communities including case management, 4) Data collection and social science research for public health decision making and 5) Support access to continuous education, social protection, child protection and Gender Based Violence (GBV) services (UNICEF, 2021).

Since the last year, coronavirus has hit the economies hard. More than 2.5 million people lost their lives, a million others lost their jobs and more than 130 million people are living in extreme poverty due to crisis. Developed countries are expected to experience a much deeper fall in output than developing countries (UNCTAD, 2020). 


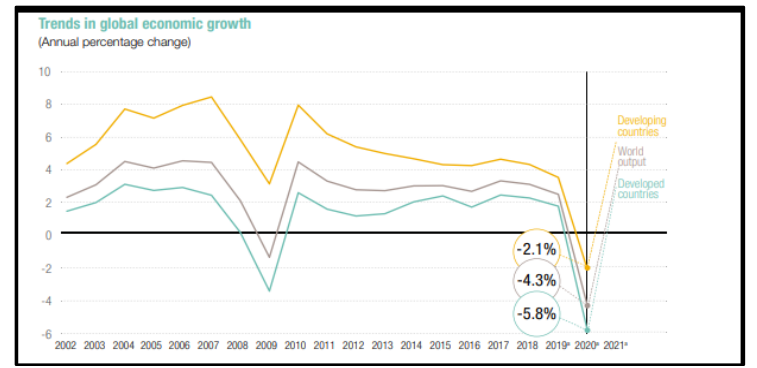

Fig 1: Trends in global economic growth Source: UNCTAD, 2020

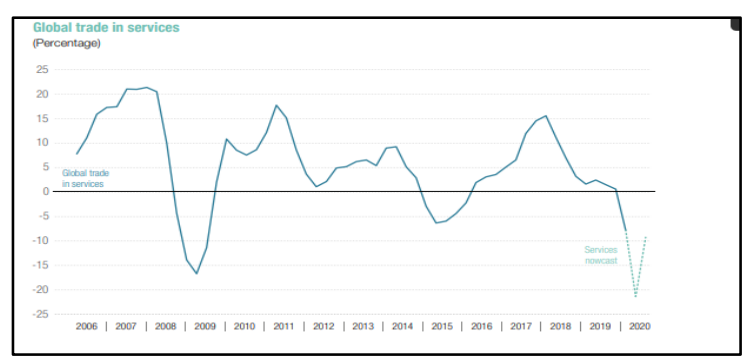

Fig. 2: Global trade in services Source: UNCTAD, 2020.

Due to lockdown world trade was the first to decline. The value of total trade in services fell by $7.6 \%$ in the first quarter of 2020 especially the travel and services sector hit hard and fallen by more than 24\%. World Economic Forum estimated that $93 \%$ of world workers are living under workplace restrictions and the whole world lost $8.8 \%$ of working hours. Europe lost $14.6 \%$ of working hours and America lost $13.7 \%$. In 2020 the total job losses were 114 million. Many organization offer flexible work hours ( Mewafarosh et al, 2021;Sadhna et al, 2020) OECD (Organisation for Economic Cooperation and Development) released a forecast that developed countries are projected to experience a decline in GDP of $5.5 \%$ in 2020 and positive growth of $3.2 \%$ in 2021 while developing countries will experience negative growth of $3.0 \%$ in 2020 and a positive growth of $5.1 \%$ in 2021. (GEEC, 2020).

Covid-19 and Indian Economy: The countrywide lockdown has brought nearly all economic activities to an abrupt halt. The second wave of the coronavirus is proving more dangerous than the first and the covid-19 cases in India are increasing abruptly. India's economic crisis operates at two levels- supply-side disruptions and reductions in aggregate demand. An assessment was made by taking 5 key economic indicatorsGDP, Unemployment rate, Inflation rate, Interest rate, and Industry output. International Monitory Fund slashed India's growth rate for the fiscal year 2021 to $1.9 \%$ from $5.8 \%$. Domestic agency CRISIL predicted India's economic rate to $1.8 \%$ from $3.5 \%$. Covid-19 hit hard India's agriculture sector and blocked all necessary channels of input, distribution, harvesting, procurement, transport channels, marketing, and processing processes. The harvesting process is worst affected due to the lack of availability of migrant workers as March-April is the peak season of Rabi Crop (Kumar, 2020). During 2018-2019, India exported medicines to more than 200 countries of about $\$ 19$ billion but as the supply chain was affected badly by Covid-19, India limits the export of 26 large quantities of medicines.

Table 1 : Impact of Covid-19 on various Indian sectors. Source: Kumar et al. 2020

\begin{tabular}{|c|c|c|}
\hline $\begin{array}{l}\text { S. } \\
\text { No. }\end{array}$ & $\begin{array}{l}\text { Sectors affected by Covid- } \\
19\end{array}$ & $\begin{array}{l}\text { Decrease } \\
\text { in } \\
\text { Percentage }\end{array}$ \\
\hline 1. & $\begin{array}{l}\text { Financial, Real Estate and } \\
\text { Professional Services }\end{array}$ & $20 \%$ \\
\hline 2. & Mining and Quarrying & $17 \%$ \\
\hline 3. & $\begin{array}{lll}\text { Electricity, Gas, } & \text { Water } \\
\text { Supply and other } & \text { utility } \\
\text { service } & & \end{array}$ & $16 \%$ \\
\hline 4. & Construction & $15 \%$ \\
\hline 5. & $\begin{array}{l}\text { Trade, Hotels, Transport, } \\
\text { Communication and other } \\
\text { broadcasting service }\end{array}$ & $11 \%$ \\
\hline 6. & Overall CVA & $11 \%$ \\
\hline 7. & Manufacturing & $7 \%$ \\
\hline 8. & $\begin{array}{l}\text { Agriculture, forestry and } \\
\text { fishing }\end{array}$ & $2 \%$ \\
\hline 9. & $\begin{array}{l}\text { Public Administration, } \\
\text { Defence and Other service }\end{array}$ & $1 \%$ \\
\hline
\end{tabular}

\section{Atmanirbhar Bharat}

After the severe crisis in all major sectors, it was mandatory for the government not to just boost the economy but also to provide a new ray of hope in the minds of 135 crore people. Workers were started migrating, manufacturing hubs were closed, transportation was not there; these all factors along with others hit the economy hard. To get things back on track, PM Modi announced a Covid-19 special economic package of 20 lakh crores on the $12^{\text {th }}$ of May, 2020. The package was based on 5 pillars: Economy, Infrastructure, System, Vibrant Demography, and Demand. The package was equivalent to 
$10 \%$ of India's GDP and was announced to boost cottage industry, MSMEs, labourers, middle class, industries, and others. The package will be distributed in 5 phases:

Table 2: Phases of Atmanirbhar Bharat Source: GoI (Ministry of Finance)

\begin{tabular}{|l|l|}
\hline Phase 1 & Businesses including MSME's \\
\hline Phase 2 & Poor including migrant and farmers \\
\hline Phase 3 & Agriculture \\
\hline Phase 4 & New horizons of growth \\
\hline Phase 5 & Govt. reforms and enablers \\
\hline
\end{tabular}

Recently the Atmanirbhar package 3.0 was announced by the finance minister $\mathrm{N}$. Sitharaman on $12^{\text {th }}$ November 2020, and has 4 parts.

Table 3: Items under package. Source: Atmanirbhar Package 3.0, Ministry of Finance.

\begin{tabular}{|l|l|c|}
\hline $\begin{array}{c}\text { S. } \\
\text { No. }\end{array}$ & \multicolumn{1}{|c|}{ Items } & $\begin{array}{c}\text { Rs. } \\
\text { Crores }\end{array}$ \\
\hline 1. & $\begin{array}{l}\text { Pradhan Mantri Garib } \\
\text { Kalyan Package (PMGKP) }\end{array}$ & $1,92,800$ \\
\hline 2. & $\begin{array}{l}\text { Atmanirbhar Bharat } \\
\text { Abhiyan 1.0 11,02,650 }\end{array}$ & $\begin{array}{l}\text { PMGKY Anna Yojana } \\
\text { Extension - 5 months Jul- } \\
\text { Nov }\end{array}$ \\
\hline 3. & $\begin{array}{l}\text { Atmanirbhar Bharat } \\
\text { Abhiyan 2.0 (12 }\end{array}$ & 73,000 \\
\hline 5. & $\begin{array}{l}\text { Atmanirbhar October) } \\
\text { Abhiyan 3.0 Bharat }\end{array}$ & $2,65,080$ \\
\hline 6. & $\begin{array}{l}\text { RBI Measures announced till } \\
31 \text { st Oct. 2020 12,71,200 }\end{array}$ & $\mathbf{2 9 , 8 7 , 6 4 1}$ \\
\hline & Total & \\
\hline
\end{tabular}

For the Covid-19 Vaccine and its related research and development finance minister grants 900 crores under the Atmanirbhar bharat package. Government also approved 1500 crore to the department of pharmaceutical to incentivize the global and domestic players to engage in high value production of medical drugs (Aparna, 2020). Basic objective of the package is to focus and accelerate the pre-clinical trials and clinical development of Covid-19 vaccines in India.

\section{RESEARCH METHODOLOGY}

The research paper is of qualitative type and secondary data was extracted and analysed through a qualitative software tool NVivo 12 (Trial Version). The research unfolds in two phases: 1. The secondary data such as government reports, research papers, and magazines were collected and information regarding Covid-19 was analysed. The impact of Covid-19 was noted down on various sectors globally and various that are been taken by countries to revive the economies were also noted down and; the second phase of research deals with the analysis of the Atmanirbhar Bharat scheme under which the Indian government released the special economic package of 20 lakh crore. Data was extracted using the \#Atmanirbharbharat from Twitter in between 12 $12^{\text {th }}$ May, 2020 to $11^{\text {th }}$ April, 2021 (10:09:52AM) using N Capture and total of 15018 tweets were extracted and then analysed on qualitative software tool NVivo.

\section{DATA ANALYSIS}

The extracted data was analysed by qualitative software tool NVivo. NVivo 12 (trial version) of the software was used and a number of parameters were identified. The data set revealed that the government was well aware of the sectors which were affected badly by Covid19. The economic package under the AtmanirbharBharat was designed to keep everyone's interest in mind.

\section{Themes Identified}

NVivo 12 enables automated "topic modelling" or the automated identification of themes from text sets and text-based datasets. NVivo enables to extraction of the themes out of the topic \#Atmanirbharbharat. Table 4 represents the major themes that were extracted under Atmanirbharbharat package.

Table 4: Various themes identified under Atmanirbharbharat.

\begin{tabular}{|l|c|}
\hline $\begin{array}{l}\text { Themes } \\
\text { Identified }\end{array}$ & $\begin{array}{c}\text { A : Files } \backslash \text { \#atmanirbharbharat } \\
\text { - Twitter Search } \sim \text { Twitter }\end{array}$ \\
\hline 1: missile & 812 \\
\hline 2: product & 369 \\
\hline 3: range & 1539 \\
\hline 4: requirements & 776 \\
\hline 5: ships & 808 \\
\hline
\end{tabular}

It can be seen from the thematic analysis, the top 6 themes identified are revolving about Make In India product specially defence equipment.

\section{Sentiment Analysis}

In recent years a lot of work has been done in the field of "Sentiment Analysis on Twitter by a 
number of researchers. In its early stage, it was intended for binary classification which assigns opinions or reviews to bipolar classes such as positive or negative only but NVivo 12 allows to extract up to four sentiments as seen in the mentioned graph (Gupta et al, 2020; Kharde and Sonawane, 2016). There are automated ways to extract sentiment from the written text as well as from tweets that were posted on Twitter. With sentiment analysis techniques, we can automatically analyse a large amount of available data and extract opinions that may help both customers and organization to achieve their goals. This is one of the reasons why sentiment analysis has been spread in popularity from computer science to management and social sciences (Farhadloo and Rolland, 2016).

Table 5: Sentiment analysis

\begin{tabular}{|l|c|}
\hline Sentiments & $\begin{array}{c}\text { \#atmanirbharbharat - Twitter } \\
\text { Search } ~ \text { Twitter }\end{array}$ \\
\hline $\begin{array}{l}\text { 1: Very } \\
\text { negative }\end{array}$ & 422 \\
\hline $\begin{array}{l}\text { 2: Moderately } \\
\text { negative }\end{array}$ & 1067 \\
\hline $\begin{array}{l}\text { 3: Moderately } \\
\text { positive }\end{array}$ \\
\hline $\begin{array}{l}\text { 4: Very } \\
\text { positive }\end{array}$ \\
\hline
\end{tabular}

Table 5 represents the sentiment analysis of people based on tweets. Most of the tweets are moderately positive followed by moderately negative. It is clearly visible that only a few tweets are very positive.. Overall, it is visible that the Atmanirbharbharat is viewed positively by Twitter users.

\section{Word Map and Word Cloud}

A word cloud is a word frequency query used to generate a word cloud and help you find commonly used words and phrases. This is useful as an end product and a good tool to help you learn about what is going on with your data. This represents the key and main areas of discussion and this is quite evident from the picture below that all the tweets were revolving around "AtamNirbhar Bharat" Campaign, trainings, Indian products etc The word Atmanirbharbharat is at the centre and is surrounded by words mostly related to healthcare and coronavirus, which were supposed to be surrounded by the words like an entrepreneur or related.

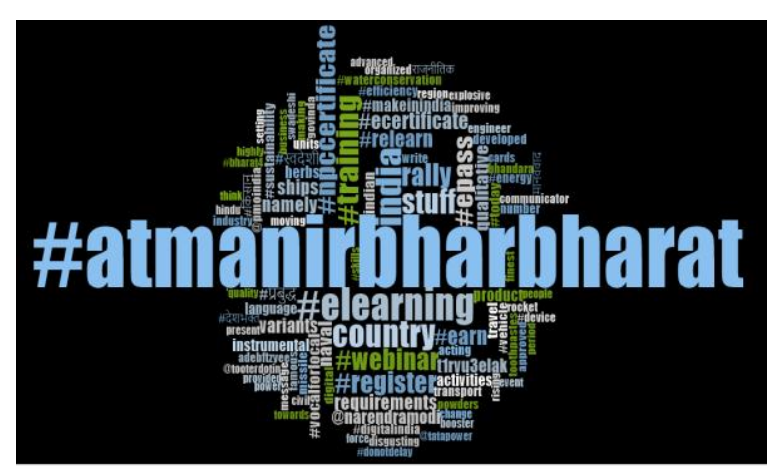

Figure 5: Word Cloud

Word world map is the generation of tweets based on geographical locations worldwide. Fig 6 indicates that most of the tweets are from India and rest of the tweets are from America and very few are from Europe and Australia.

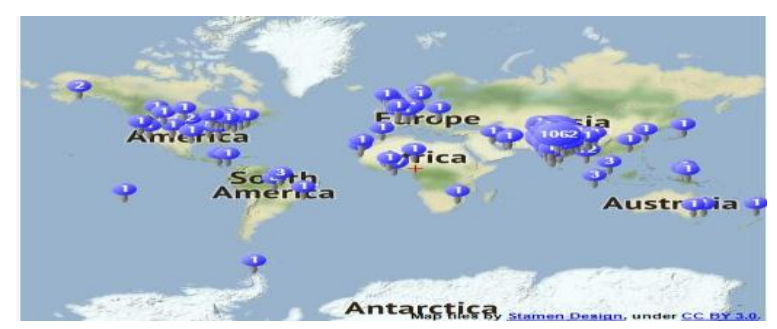

Fig 6: Word Map.

Fig. 6 represents the word cloud where the keywords are represented according to their frequency in the data set. As the Tweets were extracted in Corona period this is quite evident world was looking toward India for vaccination. The word Atmanirbharbharat is well protected by the words related to development (digital India, product, quality and power) and on the other side by words related to training (relearn, make in India and efficiency).

\section{DISCUSSION}

Atmanirbharbharat package was introduced to revive the economy that was fall flat due to Covid-19. This special economic package was released in such a way that it supports all the sectors that were hit hard by Covid-19. The Atmanirbhar package aimed to strengthen the manufacturing process, enhance employment opportunities, and boost entrepreneurship among youth so that the economy get back on track. Migrant laoburers, farmers, and street vendors were at the top for whom the package was released. The package was announced to lighten the ray of hope in the minds of people. However, government announced it but it was 
hard to channelise the things to 135 crore people and the results are also pointing to the same. The things were not properly managed as it should be.

The first set of relief measures was focused on Indian MSMEs (Micro, Small, and Medium Enterprises) and 6 announcements were dedicated to MSMEs out of 16 announcements. The government tries to improve the economy and for this MSMEs were the first and the prime targets. The central government also addresses the state governments to further clarifies all the doubts in the minds of people regarding to the package and also advised them to channelise the package.

The government also advised the banks to support the MSMEs for funds and these various schemes were announced under employment generation program, development of traditional industries, entrepreneurship, and skill development programs. The basic idea behind strengthening the MSMEs is to make India a manufacturing hub rather than a marketing hub. The intention was clear to produce finished products in India by adding value to raw materials. Under Atmanirbharbharat push government has focused on being "vocal for local".

The scheme was launched in three phases and all three phases were total of reforms for business, employment, and manufacturing. The third phase of the economic package was made to ensure the employment push in the formal sector. The phase will run for three years from 2020 to 2023 and will provide ample employment opportunities. The package focuses on the development of skills through training and development program, to improve living standards and to empower migrant and farmers affected by the pandemic.

The paper examined the theoretical background of the Atmanirbharbharat scheme and also addressed the issues related to the special economic package. Both the negative and positive sentiments were examined in this paper through tweets on Twitter. No doubt it is one of the concrete steps to boost the economy under the five pillars- economy, infrastructure, system, vibrant demography and demand. It is a hierarchical development that will starts from labourers and farmers and will end up at the top with better employment opportunities.

\section{CONCLUSION}

All countries are engaged in a fight against Covid-19 in their way. Countries are imposing lockdowns, restricting flights and aviation, to aware the people about the consequences, and some of the countries have even been successful in it. It will take years to recover the damage that has been done to economies by Covid-19. Countries are trying hard to satabilize the economies by announcing the Covid-19 relief packages. The Indian government announced the special economic package under Atmanirbharbharat to revive the economy. Under the Atmanirbharbharat package, an extensive focus was made on reshaping the economy by aligning all sectors in one direction. Things were looking stable and everything started happening as before Covid-19, but the second wave of coronavirus has scrapped all the plans and actions. Atmanirbharbharat package along with the start of the vaccination process has reduced the fear of Covid-19 in the minds of people but the second wave has stagged the healthcare system.

Atmanirbharbharat relief package is still out of reach and there is a state of confusion in the minds of people. People are not getting basic health care facilities. Government has to take care of the implementation process of the Atmanirbharbharat package and the basic system has to be fixed.

\section{REFERENCES}

Arora, N., \& Gupta, V. (2020). Study on impact of Covid-19 on Indian economy. International Journal of Science and Research, 9(7), 1516-1518. Doi10.21275/SR20724142409.

Atmanirbhar Bharat Abhiyan Phase 1-5- to Support Indian Economy in Fight Against Covid-19. (2020). Ministry of Finance. Retrieved from https://Covid19.india.gov.in/documentcategory/ministry-of-finance/.

Atmanirbharbharat FM grants 900cr for Covid19 Vaccine research. (2020, November 12). Retrieved from https://www.livemint.com/news/india/ atmanirbhar-bharat-fm-grants-rs-900-crfor-covid-19-vaccine-research$\underline{11605172686255 . h \mathrm{tml}}$.

Biswas, S. (2021, April 19). Covid-19: How India failed to prevent a deadly second wave. 
BBC News. Retrieved from https://www.bbc.com/news/world-asiaindia-56771766.

Barbate, V., Gade, R.N., \& Raibagkar, S.S. (2021). Covid-19 and its impact on Indian economy. Vision- The Journal of Business Perspective, 25(1).

Covid-19 pandemic monthly external situation. (2021). UNICEF India, Report no. 8, 2-7. Retrieved from https://www.unicef.org/india/reports/u nicef-india-covid-19-situation-report-mo.8.

Dubey, S., \& Dubey, H.K. (2020). Atmanirbhar bharat abhiyan: An analytical review. Dogo Rangsang Research Journal, 10(7), 2728.

Farhadloo, M., \& Rolland, E. (2016). Fundamentals of sentiment analysis and its applications. Springer International Publishing Switzerland. Doi10.1007/978_3_319_30319_2_1.

France to spend $100 \mathrm{bn}$ euros on stimulus plan to revive economy. (2020, September 03). Retrieved from https://irishtimes.com/business/econom $\mathrm{y} /$ france-to-spend-100bn-on-stimulusplan-to-revive-economy-1.4345636.

Global economic effects of Covid-19. (2021). Congressional Research Service. Retrieved from

https://crsreports.congress.govR46270.

Government launches mission Covid-19 suraksha to accelerate Indian Covid-19 vaccine development. (2020). Ministry of Science and Technology. Retrieved from https://www.pib.gov.in/PressRelease1fra mePage.aspx?PRID=1676998.

Hays, R., \& White, G. D. (2015). The care.data consensus? A qualitative analysis of opinions expressed on twitter. BMC Public Health. Doi- 10.1186/s12889-015-2180-9.

Japee, G. (2020). Atmanirbhar Bharat. Research gate, 3-4. Doi10.13140/RG.2.2.18715.69928.

Impact of Covid-19 pandemic on trade and development. (2020). United Nations Conference on Trade and Development. Retrieved from https://unctad.org/system/files/officiald ocument/osg2020d1_en.pdf\&ved=2ahUK Ewj7m8H57Z7wAhVhwTgGHc_MCzYQF
jAMegQIBhAC\&usg=AOvVaw2TdWFz0pJ-AwxcNKofnSu

Kaurav, R.P.S., Suresh, K.G., Narula, S., \& Baber, R. (2020). New education policy: Qualitative (contents) analysis and twitter mining (sentiment analysis). Journal of Content, Community $\mathcal{E}$ Communication, 12(6). Doi: 10.31620/JCCC.12.20/02.

Kharde, V.A., \& Sonawane, S.S. (2016). Sentiment analysis of twitter data: A survey of techniques. International Journal of Computer Applications, 39(11).

Mahajan, A.S. (2021, May 4). The cost of lockdowns. India Today, XL16, 19, 8-9.

Managing India's second Covid-19 wave: Urgent steps. (2021). The Lancet Covid-19 Commission. India Task Force. Retrieved from

https://static1.squarespace.com/static/5e f3652ab722df11fcb2ba5d/t/6076f57d3b43f $\underline{\mathrm{b} 2 \mathrm{db} 4 \mathrm{a} 7 \mathrm{c} 9 \mathrm{c} 9 / 1618408831746 / \text { India }+\mathrm{TF}+\mathrm{P}}$ olicy+Brief+April+2021.pdf.

Mewafarosh, R., Tripathi, V., \& Gupta, S. (2020). A conceptual study: organisation culture as an antecedent to employee engagement. International Journal of Environment, Workplace and Employment, 6(1-2), 3-19.

Narayanan, D. (2021, March 06). America's \$1.9 trillion rescue package could throw a spanner in RBI's recovery plans. The Economic Times. Retrieved from https://economictimes.indiantimes.com/ news/economy/policy/americas-\$1.9trillion-rescue-package-could-throw-aspanner-in-RBI's-recovery-plans/article show/ 81367635.cms.

Novel coronavirus disease (COVID-19). (2021). World Health Organization India, Report no. 66. Retrieved from https://www.cdn.who.int/media/docs/ default-source/wrindia/situationreport/india-situation-report66.pdf?sfvrsn=24f9349d_4.

Patnaik, I., \& Sengupta, R. (2020). Impact of Covid-19 on the Indian economy: An analysis of fiscal scenarios. NIPFP Working Paper Series No. 319. Retrieved from https://www.nipfp.org.in/publications/ working-papers/1916/ 
Pudaruth, S., Moheeputh, S., Permessur, N., \& Chamroo, A. (2018). Sentiment analysis from faceboook comments using automatic coding in NVivo 11. Advanced in Distributed Computing and Artificial Ibtelligence Journal, 7(1).

Sandeep, K.M., Maheshwari, V., Prabhu, J., Prasanna, M., Jayalakshmi, P., Suganya, P., Benjula, M.B., \& Jothikumar, R. (2020). Social economic impact of Covid-19 outbreak in India. International Journal of Pervasive Computing and Communications, 16(4), 311-314.

Gupta, S., Sharma, J., Najm, M., \& Sharma, S. (2020).Media Exaggeration And Information Credibility: Qualitative Analysis Of Fear Generation For Covid-19 Using Nvivo. Journal of Content Community and Communication, 12(6). 14-20

Staff, R. (2020, September 29). How the global coronavirus pandemic unfolded. Reuters. Retrieved https://reuters.com/article/healthcoronavirus-timeline-idUSL1N2GN04I.

Sadhna, P., Gupta, S., \& Rastogi, S. (2020). Key motivators for driving work performance amid COVID-19 in developing nations. International Journal of Work Organisation and Emotion, 11(2), 105-119.

Sood, M., Sharma, B., Gupta, S., Dawra, S., \& Kaushik, C. (2019). Modelling the Factors

Responsible for Better Health Service Quality: Perception of Service Providers. Indian Journal of Public Health Research \& Development, 10(9), 408-413.

Supriya, L. (2021, April 27). Triple mutation in SARS-CoV-2 seen in second wave of Covid-19 in India. News Medical Life Sciences. Retrieved from https://www.newsmedical.net/news/20 210427/Triple-mutation-in-SARS-CoV-2seen-in-second-wave-of-Covid-19-inindia.aspx. 